С. А. Бузько

\title{
ПОНЯТТЯ СТИЛІСТИЧНОЇ МАРКОВАНОСТІ МОВНИХ ЗАСОБІВ (ЗАГАЛЬНОТЕОРЕТИЧНИЙ АСПЕКТ)
}

\author{
Бузько С. А. Поняття стилістичної маркованості мовних засобів \\ (загальнотеоретичний аспект). \\ У статті описано основні наукові підходи до визначення поняття стилістичної \\ маркованості мовних засобів. Стилістична маркованість (стилістичне забарвлення) \\ розглядається як наявність у мовної одиниці додаткової конотативної інформації \\ емоційного, експресивного, оцінного чи стильового характеру, що зумовлює здатність \\ цієї одиниці створювати певний стилістичний ефект, надаючи мовленню, залежно від


комунікативно-прагматичної настанови мовця, різних відтінків - урочистості, піднесеності, невимушеності, фамільярності, іронічності, гумору, комізму, згрубілості, агресивності тощо.

Ключові слова: стилістична маркованість, стилістичне забарвлення, мовна норма, стилістичне значення, конотація.

Бузько С. А. Понятие стилистической маркированности языковых средств (общетеоретический аспект).

В статье описаны основные научные подходы к определению понятия стилистической маркированности языковых средств. Стилистическая маркированность (стилистическая окраска) рассматривается как наличие в языковой единице дополнительной коннотативной информации эмоционального, экспрессивного, оценочного или стилистического характера, что обуславливает способность этой единицы создавать определенный стилистический эффект, наделяя речь, в зависимости от коммуникативно-прагматической установки, различными оттенками - торжественности, возвышенности, непринужденности, фамильярности, ироничности, юмора, комизма, грубости, агрессивности и т. д.

Ключевые слова: стилистическая маркированность, стилистическая окраска, языковая норма, стилистическое значение, коннотация.

Buzko S. A. Stylistic marking notion of language means and devices (general theoretical aspect).

This article investigates the basic linguistic approaches of defying stylistic marking of language means and devices. Stylistic marking (stylistic expressiveness) is considered as supplying a language unit with additional connotative information expressing emotional, evaluative or stylistic nature. It determines the ability of the unit to create a stylistic effect. It also forms special effect to the speaker's message according to communicative and pragmatic speaker's intentions, making the speech more ceremonial and high spirited, informal, familiar, ironic, humorous, comic, rude, aggressive etc. The concept, known in linguistics called stylistic marking, covers a wide range of material and functionally disparate phenomena. Stylistically be labeled individual sounds or their compound word word creative means, syntactic constructions and so on. The article discusses some of the interpretations of the deadline and it being denoted linguistic phenomena.

It is noted that in modern linguistics phenomenon stylistic marking understood differently. Some researchers consider it in relation to the concept of linguistic rules, other scientists notion of stylistic markedness associated with stylistic value and the presence of a linguistic unit different connotations. At the same time in the style widely used term "stylistic expressiveness", which usually means a linguistic unit correlation with certain functional style language. Some researchers stylistic expressiveness is defined as the presence of additional words semantic and stylistic nuances.

Key words: stylistic marking, stylistic expressiveness, language norm, stylistic meaning, connotation.

Серед категорій, що складають поняттєвий апарат лінгвостилістики, стилістична маркованість є однією 3 ключових i () С. А. Бузько, 2016. 
найбільш загальних. У сучасній лінгвістиці термін «маркованість» розуміється по-різному. Одні дослідники, за спостереженнями I. Гальперіна, витлумачують маркованість як здатність мовної одиниці виявляти додаткові семантичні або стилістичні відтінки. Інші розглядають явище маркованості як наявність диференційної ознаки, що відрізняє одну форму використання мовної одиниці від інших, протилежних форм, які характеризуються відсутністю такої ознаки [6, с. 269]. Поняття, відоме в лінгвістиці під назвою стилістичної маркованості, охоплює широке коло матеріально та функціонально різнорідних явищ. Стилістично маркованими можуть бути окремі звуки чи їх сполуки, слова, словотвірні засоби, синтаксичні конструкції тощо. Розглянемо деякі трактування зазначеного терміна та позначуваних ним мовних явищ.

У ряді досліджень явище стилістичної маркованості пов'язується 3 поняттям мовної норми, при цьому простежується переважно два різні погляди на проблему співвідношення стилістичної маркованості 3 мовною нормою. Одні дослідники вбачають у явищі стилістичної маркованості неминуче «мотивоване відхилення від лінгвістичних або будь-яких інших загальноприйнятих норм» [18, с. 131]. Інші вважають, що в стилістично маркованому явищі «немає нічого, чого не було б у мові - як системі і в мові - як реалізації цієї системи, тобто в мовленні» [6, с. 275]. Наявна також третя концепція, згідно 3 якою розрізняють два типи стилістично маркованих явищ: негативний, що являє собою порушення норми, й позитивний, який перебуває в межах мовної норми [8, с. 137].

Грунтовний опис дії принципів стилістичної маркованості міститься у працях І. Гальперіна. Розглядаючи досліджуване явище переважно на рівні тексту, учений розуміє під маркованістю такі «синтаксичні побудови або смислові зв'язки компонентів висловлення, які характеризуються одночасно незвичністю використання, обмеженим ступенем допустимості, інколи навіть граматичною неправильністю. Вони обов'язково передають додаткову інформацію» 
[6, с. 271]. Опозиція маркованість / немаркованість поєднує в собі, на переконання дослідника, деякі ознаки таких типів опозицій, як правильність / неправильність, звичайність / незвичайність, допустимість / недопустимість, причому слабкий член цієї опозиції немаркованість - повністю або частково збігається з сильними членами інших опозицій - правильністю, допустимістю та звичністю використання. Саме вмотивоване й свідоме порушення загальномовної норми, яка асоціюється з правильністю та стандартністю, породжує, на думку вченого, явище стилістичної маркованості.

О. Бєляєвська, пов'язуючи явище стилістичної маркованості 3 комунікативною прагматикою, виокремлює три групи явищ, співвідносних із поняттям стилістичної маркованості:

1) стилістична маркованість тексту або уривка тексту як вказівка на його належність до певного функціонального стилю чи жанру в межах стилю;

2) стилістична маркованість частини тексту, зумовлена таким уживанням мовних одиниць різних рівнів, яке містить стилістичну інформацію (цей тип стилістичної маркованості може бути властивий також одиницям мови, що реалізуються в тексті);

3) стилістична маркованість мовної одиниці як елемента системи, тобто стилістична значущість як онтологічна властивість мовного знака [4, с. 21].

Ряд інших дослідників (зокрема Т. Винокур, Л. Мацько, О. Мацько, Е. Різель, О. Сидоренко) явище стилістичної маркованості пов'язують із наявністю в мовній одиниці стилістичного значення, під яким розуміють загальне позначення емоційного, експресивного та експресивно-образного значення. На думку Т. Винокур, до вивчення стилістичного значення варто підходити 3 інформативнокомунікативних позицій, «тобто враховувати його здатність бути опорним пунктом стилістичного комплексу, який обслуговує мовленнєве спілкування (засіб - прийом - завдання / ефект). Ця здатність, що спонукає нас уважати стилістичне значення ключовим 
поняттям стилістики, $є$ наслідком його семантичної природи, що зумовило й вибір самого терміна» [5, с. 43]. Дослідниця доводить, що термін «стилістичне значення» певною мірою корелює (відповідно до його функціонально-комунікативної інтерпретації) 3 поняттямитермінами «стилістичний засіб», «стилістичний прийом», «стилістичне завдання», «стилістичний ефект», а також узагальнює сутність такого поняття, як «експресивні відтінки» та відповідає певному типу експресивної семантики, яка ускладнює лексичне або граматичне значення одиниць мови.

Концепція стилістичного значення, запропонована Е. Різель, доводить існування двох видів цієї категорії: стилістичне значення в парадигматичному та синтагматичному (контекстуальному) аспектах. Перший вид, який дослідниця називає абсолютним стилістичним значенням або абсолютною стилістичною маркованістю, задається самою системою мови й тому є необхідною передумовою для адекватного використання можливостей мови під час їх реалізації в мовленні.

Стилістичне значення в синтагматичному аспекті пов'язане передовсім із стилістичним забарвленням лексеми в певному контексті (контекстуальне або актуальне стилістичне забарвлення), під яким мовознавець має на увазі стилістичну характеристику мовних одиниць у зв'язному мовленні, яка може змінюватись або залишатись постійною відносно абсолютної стилістичної маркованості. Іншим фактором, який безпосередньо впливає на стилістичне значення як у парадигматичному, так і в синтагматичному аспектах, Е. Різель уважає конотацію, «яка витікає або безпосередньо 3 контекстуального стилістичного забарвлення, або 3 усієї інформації» [13, с. 138]. Дослідниця наголошує на тому, що названі лінгвістичні категорії стилістичне значення і конотація - певною мірою взаємопов'язані, але не тотожні, оскільки конотація - це додаткова інформація, виражена в невербальній формі. «Незважаючи на те, що ми розглядаємо конотацію як лінгвістичну категорію, вона тим не менш $є$ й залишається 
асоціацією, яка має смисловий, емоційний і волюнтативний характер $<\ldots>$. Вона не виражається вербально, але ऑiі можна зрозуміти 3 експліцитного, реально вираженого змісту» [13, с. 138]. Урешті лінгвіст доходить висновку, що стилістичне значення у зв'язному мовленні може бути оцінене як конотативне стилістичне значення, оскільки в ньому переважає конотація.

На думку українських стилістів Л. Мацько, О. Сидоренко, О. Мацько, стилістичне значення - це «додаткове, супровідне до лексичного та граматичного значення мовної одиниці», тісно пов'язане зі «стилістичною вартістю» слова (тобто маркованістю), яка обмежує його використання певним стилем, типом мовлення чи видом тексту. Розрізняють стильове і стилістичне значення. Стильове значення мовної одиниці нерозривно пов'язане з ії маркованістю й показує, у якому функціональному різновиді (стилі) ця одиниця зазвичай функціонує. Стилістичне значення діє в межах стильового на тлі стилістично нейтральних мовних засобів і характеризується конкретною оцінністю, емоційністю, експресією. «Воно виникає в результаті асоціативнообразного переосмислення значення, нашарування твірної семантики суфіксів, ситуативного використання слів» [10, с. 194-195].

Деякі лінгвісти (наприклад, Н. Бабич та М. Пилинський) стилістичну маркованість розуміють як закріпленість слова за певним функціональним стилем мови. У зв'язку з цим слова будь-якої мови Н. Бабич розподіляє на дві категорії: 1) стилістично нейтральні та 2) стилістично марковані, тобто закріплені за певним стилем. «Стилістично нейтральні слова - це слова загальновживані, а стилістично марковані, або слова вузького стилістичного призначення, - це лексеми 3 певним стилістичним відтінком» [2, с. 53]. М. Пилинський, аналізуючи це явище, зосереджує увагу на процесах зміни маркованості ряду лексичних одиниць. Учений зазначає, що слово, реалізуючи свій активний внутрішній потенціал, перебуває в постійних узаємодіях зі своїм оточенням, 3 різними типами контекстів, у яких воно функціонує. «Цим i зумовлене 
переміщення слова 3 одного стилю мовлення в інший, зміна його стилістичної маркованості» [11, с. 133-134].

Інші дослідники надають перевагу терміну «стилістичне забарвлення», також співвідносячи його 3 належністю слова до певного стилю мови (Л. Барлас, І. Голуб, Г. Їжакевич, О. Пономарів).

«Закріпленість за тим чи тим стилем наділяє слово певним стилістичним «паспортом», - стверджує Л. Барлас, - який і служить сигналізатором його стилістичного забарвлення» [3, с. 149]. Стилістичне забарвлення слова вчений пов'язує з його емоційною оцінкою, наголошуючи на тому, що ці категорії взаємопов'язані, але не тотожні. «Стилістичне забарвлення - категорія оцінна. Але на відміну від емоційного забарвлення, воно спрямоване не на сам об'єкт, який називає слово (річ, особу, дію, якість і т. ін.), а на саме слово, на саме мовлення» [3, с. 150]. Так, слова 3 підвищеним стилістичним забарвленням (книжна, висока, поетична лексика) характеризують мовлення як емоційно-підвищене, урочисте; слова зі стилістично зниженим забарвленням (розмовним, просторічним, грубо просторічним), навпаки, характеризують мовлення як звичнопобутове, містять натяк на мовленнєву ситуацію, на стосунки мовців тощо; слова ж, які звикли називати нейтральними, ніяк не оцінюють мовлення - вони мають нульове стилістичне забарвлення.

I. Голуб також використовує термін «стилістичне забарвлення», яке, на думку дослідниці, «залежить від того, як слово сприймається нами: як закріплене за тим чи тим стилем чи як доречне в будь-якій мовленнєвій ситуації, тобто загальновживане» [7, с. 99].

Г. Їжакевич та О. Пономарів стилістичне забарвлення слова пов'язують передовсім із його використанням у певному функціональному стилі. Усі слова сучасної української мови, відповідно, учені поділяють на дві великі групи: стилістично нейтральні слова, якими послуговуються в усіх стилях, i слова, стилістично забарвлені, які використовуються лише в окремих стилях чи в одному з них $[16$, с. $82-89 ; 12$, с. 36-38]. 
Схожої позиції дотримується I. Чередниченко, відзначаючи, що певна кількість слів у мові мають виразне «стильове забарвлення», і називає такі одиниці словами вузького стилістичного призначення, 3 певним стилістичним відтінком. Однак, - наголошує вчений, більшість слів нашої мови належить до нейтральної категорії, яка не має виразних ознак стилістичного призначення, це загальновживані слова, стилістично нейтральні [19, с. 86].

У ряді інших досліджень стилістичне забарвлення трактують як наявність у мовної одиниці різних конотацій (О. Ахманова, О. Крижановська, В. Телія та ін.). У зв'язку 3 цим «Стилістичний енциклопедичний словник російської мови» за редакцією М. Кожиної подає таке визначення стилістично забарвленої лексики: «це лексичні одиниці (однозначні слова чи окремі значення багатозначних слів), які характеризуються здатністю викликати особливе стилістичне враження поза контекстом. Ця властивість зумовлена тим, що в значенні цих слів міститься не лише предметно-логічна (відомості про позначуваний предмет) інформація, але й додаткова (непредметна) конотаціï» [14, с. 454]. У «Лінгвістичному енциклопедичному словнику» конотація тлумачиться як емоційна, оцінна або стилістична забарвленість мовної одиниці узуального (закріпленого в системі мови) чи оказіонального характеру. У широкому витлумаченні це будь-який компонент, що доповнює предметно-поняттєвий зміст мовної одиниці та надає їй експресивного забарвлення. У вузькому витлумаченні це компонент значення, змісту мовної одиниці, який виконує другорядну функцію найменування й доповнює таким чином об'єктивне значення цієї одиниці асоціативно-образним уявленням про позначувану реалію (т. зв. тропи та фігури мовлення). Асоціативно-образний компонент у структурі конотації є підставою для оцінної кваліфікації та стилістичної маркованості й пов'язує денотативний і конотативний зміст мовної одиниці [9, с. 236].

За визначенням О. Ахманової, конотація - це додаткове значення, забарвлення, «додатковий зміст слова (або вислову), його 


\section{СТРУКТУРА I СЕМАНТИКА МОВНИХ ОДИНИЦЬ}

семантичні або стилістичні відтінки, які накладаються на його основне значення, служать для вираження різних експресивноемоційно-оцінних обертонів та можуть надавати висловлюванню урочистості, ігрового характеру, фамільярності тощо» [1, с. 203-204].

Дослідниця конотативної інформації мовних одиниць В. Телія розглядає конотацію як спосіб вираження оцінки й висуває гіпотезу про те, що «конотація як експресивно маркований макрокомпонент семантики є продуктом оцінного сприйняття й відображення дійсності у процесах номінації. <..> основна функція конотації - це функція впливу, безпосередньо та нерозривно пов'язана 3 прагматикою мовлення» [17, c. 21]. Сама ж сутність творення стилістичного забарвлення, стилістичної значущості за допомогою конотації, на думку лінгвіста, доволі проста: денотативний аспект значення «обрамлюється» на основі певного асоціативно-образного мотиву емотивно-оцінною модальністю, яка, виводячи зміст висловлення з нейтрального сприйняття, створює тим самим його стилістичне забарвлення [17, с. 122]. У своїх роздумах дослідниця доходить висновку, що відношення суб'єкта мовлення, як і слухача, до світу - це відношення ціннісне (що відбиває категорія емотивності), і воно передбачає відповіді на питання: хто оцінює, що, як і 3 яких позицій; терміни цього відношення - суб'єкт (особистість із іiі смаками та світоглядом) та об'єкт (фрагмент світу в його системних зв'язках) - поєднані оцінним судженням, у якому за допомогою конотації відбивається ставлення суб’єкта до світу. Отже, під конотацією в цій концепції розуміється передовсім емотивно-оцінний компонент семантики слова чи вислову.

Відмінну від розглянутих концепцію розробила Л. Струганець, запропонувавши вивчати стилістичне забарвлення слова $з$ урахуванням семантичної трансформації та стилістичної транспозиції. «Суть семантичної трансформації, - пояснює дослідниця, - полягає в розширенні або звуженні значення вже наявного в мові слова чи в переосмисленні значення лексичної одиниці відповідно до нових реалій лінгвосоціуму» $[15$, с.97]. Відповідно, слово може змінювати своє 
стилістичне забарвлення, набувати нових семантико-стилістичних відтінків. Динамічні зрушення в напрямку стилістичної транспозиції, за спостереженнями науковця, також різнопланові. У сучасній українській мові відбуваються процеси переорієнтації номінацій, реактивації та пасивізації деяких лексико-семантичних засобів, зміни соціальних конотацій, термінологізації і детермінологізації лексичних одиниць тощо. Усі ці процеси, суть яких полягає у зміні функціонально-стильового призначення слова, скеровані передовсім на збагачення української літературної мови новими лексичними одиницями [15, с. 93-98].

Отже, у сучасній лінгвістиці явище стилістичної маркованості розуміють по-різному. Одні дослідники розглядають його у співвідношенні 3 поняттям мовної норми, інші вчені поняття стилістичної маркованості пов'язують зі стилістичним значенням та наявністю в мовної одиниці різних конотацій. Водночас у стилістиці активно використовується термін «стилістичне забарвлення», під яким зазвичай розуміють співвіднесеність мовної одиниці 3 певним функціональним стилем мови. Деякі дослідники стилістичне забарвлення визначають як наявність у слова додаткових смислових та стилістичних відтінків. У нашому розумінні стилістична маркованість (стилістичне забарвлення) - це наявність у мовної одиниці додаткової конотативної інформації емоційного, експресивного, оцінного чи стильового характеру, що зумовлює здатність цієї одиниці створювати певний стилістичний ефект, надаючи мовленню, залежно від комунікативно-прагматичної настанови мовця, різних відтінків урочистості, піднесеності, невимушеності, фамільярності, іронічності, гумору, комізму, згрубілості, агресивності тощо.

\section{Література}

1. Ахманова О. С. Словарь лингвистических терминов / О. С. Ахманова. - М. : Советская энциклопедия, 1966. - $606 \mathrm{c}$.

2. Бабич Н. Д. Практична стилістика і культура української мови : [навчальний посібник] / Н. Д. Бабич. - Львів : Світ, 2003. -430 с.

3. Барлас Л. Г. Об отношении стилистической окраски и эмоциональных оттенков слова к его лексическому значению / Л. Г. Барлас // Вопросы лексики и фразеологии () С. А. Бузько, 2016. 


\section{СТРУКТУРА І СЕМАНТИКА МОВНИХ ОДИНИЦЬ}

современного русского языка : сб. статей. - Ростов-на-Дону : Изд-во Ростовского унта, 1968. - С. 68-84.

4. Беляевская Е. Г. Стилистическая маркированность в языке и речи / Е. Г. Беляевская // Проблемы стилистической маркированности : сб. науч. тр. - М., 1990. - С. 38 .

5. Винокур Т. Г. Закономерности стилистического использования языковых единиц / Т. Г. Винокур. - М. : Наука, 1980. - 238 с.

6. Гальперин И. Р. О понятиях «стиль» и «стилистика» / И. Р. Гальперин // Вопросы языкознания. - 1973. - № 4. - С. 34-52.

7. Голуб И. Б. Стилистика современного русского языка : [учебное пособие] / И. Б. Голуб. - М. : Высшая школа, 1986. - 335 с.

8. Едличка А. Типы норм языковой коммуникации / А. Едличка // Новое в зарубежной лингвистике. - М. : Прогресс, 1988. - Вып. 20. - С. 135-150.

9. Лингвистический энциклопедический словарь / гл. ред. В. Н. Ярцева. - М. : Советская энциклопедия, 1990. - 685 с.

10. Мацько Л. І. Стилістика української мови : [підручник] / Мацько Л. I., Сидоренко О. М., Мацько О. М. ; за ред. Л. І. Мацько. - К. : Вища школа, 2003. - 462 с.

11. Пилинский Н. Н. Тенденции в изменении стилистической маркированности лексики современного русского языка (на материале лексикографии новейшего периода) / Н. Пилинский, Н. Хруцкая // Система і структура східнослов'янських мов : зб. наук. пр. - К. : УДПУ, 1997. - С. 133-134.

12. Пономарів О. Д. Стилістика сучасної української мови : [підручник] / О. Д. Пономарів. - К. : Либідь, 1993. - 247 с.

13. Ризель Э. Г. Стилистическое значение и коннотация / Э. Г. Ризель // Лингвистические проблемы текста : сб. науч. тр. - М., 1980. - Вып. 158. - С. 134-143.

14. Стилистический энциклопедический словарь русского языка / под ред. М. Н. Кожиной. - М. : Флинта. Наука, 2003. - 694 с.

15. Струганець Л. Динаміка лексичних норм української літературної мови XX століття : [монографія]/ Л. Струганець. - Тернопіль : Астон, 2002. - 352 с.

16. Сучасна українська мова : [підручник] / О. Д. Пономарів, В. В. Різун, Л. Ю. Шевченко та ін. - [2-е вид.]. - К. : Либідь, 2005. - 487 с.

17. Телия В. Н. Коннотативный аспект семантики номинативных единиц / В. Н. Телия. - М. : Наука, 1986. - 143 с.

18. Хэллидей М. А. К. Лингвистическая функция и литературный стиль / М. А. К. Хэллидей // Новое в зарубежной лингвистике. - М. : Прогресс, 1986. Вып. 9. - С. 116-148.

19. Чередниченко І. Г. Нариси з загальної стилістики сучасної української мови / I. Г. Чередниченко. - К. : Радянська школа, 1962. - 495 с.

Стаття надійшла до редакиій 23.06.2016 p. 